\title{
The Influence of Compensation and Work Environment towards Teacher's Job Satisfaction
}

\author{
Sri Rahayuningsih \\ SMP N 2 Pecangaan Jepara
}

\begin{abstract}
This study aims to expose the influence of compensation and work enviontment towards teachers's work satisfaction in SMP Negeri 2 Pecangaan Jepara.The data analysis used in this research were descriptive analysis, pre-requirement test analysis, and hypothesis test including simple linier regression analysis that was used to know the effect of compensation towards teachers' work satisfaction and the effect of work environment towards teachers' work satisfaction and multiple regression analysis to know the effect of compensation and work environment simultaneously towards teachers' work satisfaction. From the hypothesis testing, it is found that; $(\mathrm{I})$ there was a positive effect of compensation towards teachers' work satisfaction which revealed by $Y=55.50 \mathrm{I}+0.585 X_{1}$ with the correlation coefficient as 0.834 with contribution about 0.695 or $6905 \%$, (2) ) there is a positive effect of work environment towards teachers' work satisfaction which revealed by $Y=56.157+0.585 X_{2}$ with the correlation coefficient as 0.740 with contribution about 0.547 or $54.7 \%$, (3) there is a positive effect of compensation and work environment simultaneously towards teachers' work satisfaction which revealed by $Y=39.414+0.427 X_{1}+0.299 X_{2}$ with the correlation coefficient as 0.887 with

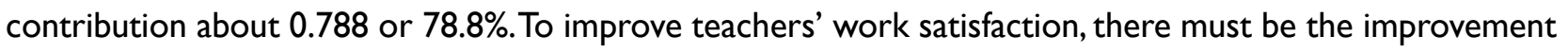
of compensation as the appreciation for teachers' and a good condition of work environment which will to the improvement of education quality.
\end{abstract}

\begin{abstract}
Abstrak
Penelitian ini bertujuan untuk memberikan keterangan tentang pengaruh kompensasi, lingkungan kerja, dan relasi keduanya terhadap kepuasan kerja guru di SMP Negeri 2 Pecangaan, Jepara. Analisis data yang digunakan adalah analisis deskriptif, uji persyaratan analisis dan uji hipotesis yang meliputi analisis regresi linier sederhana dan analisis regresi ganda. Dari uji hipotesis ditemukan: (I) terdapat pengaruh positif kompensasi terhadap kepuasan kerja guru yang dinyatakan dengan persamaan $\mathrm{Y}=$ $55,501+0,585 X_{1}$, kekuatan korelasi sebesar 0,834 dengan kontribusi sebesar 0,695 atau 69,5\%, (2) terdapat pengaruh positif lingkungan kerja terhadap kepuasan kerja guru yang dinyatakan dengan persamaan $Y=56,157+0,585 X_{2}$, kekuatan korelasi sebesar 0,740 dengan kontribusi sebesar 0,547 atau 54,7\%, (3) terdapat pengaruh positif kompensasi danlingkungan kerja secara bersama-sama terhadap kepuasan kerja guru yang dinyatakan dengan persamaan $Y=39,414+0,427 X_{1}+0,299$ $\mathrm{X}_{2}$, kekuatan korelasi sebesar 0,887 dengan kontribusi sebesar 0,788 atau $78,8 \%$. Untuk meningkatkan kepuasan kerja guru maka diperlukan peningkatan kompensasi sebagi apresiasi terhadap kinerja guru. Selain itu lingkungan kerja perlu ditingkat untuk meningkatkan kepuasan guru yang berdampak pada peningkatan kualitas pendidikan
\end{abstract}

Keywords : Compensation, work environment, teachers' job satisfaction,

\section{Corresponding author}

Email :yunipriyadi@gmail.com 


\section{Introduction}

In school management, teachers play the important part in this process because they become a bridge in all school process. The absence of teacher, will give a negative impact in order to achieve the goal of education although because the central actors of curriculum development is teacher. In Indonesia, Teachers are divided into two groups; certified and non-certified teacher, the job, duty, and awareness of them are similar. They have to be professional teacher. As stated in Law no 14 year 2005 about teacher and lecturer, Chapter 1, paragraph 1, defines teacher as a professional educator with their primary task are educating, lecturing, guiding, guarding, training, assessing, and evaluating all the process happened towards students in primary school.

Teachers become major factors in determining school achievement in gaining the education goal, because they directly engaged on school activities. They are much expected could give their high performance as educator in school. Therefore, in order to support school management to gain the education goal, it must be concern about the work satisfaction of teachers. It has to be a prior component in determining teacher's career. If the teachers do not get their job satisfaction, it brings bad impact towards their performances, motivation, innovation and presence. As a conequences, school management, and organizational work system do not run as expected.

According to Gorda in Dhermawan et all $(2012,174)$ job satisfaction become supported factor in teacher's performance improvement and contribute on improvement of school management system. School as an education instituton will get feed back from this condition. It is similar with Hasibuan explanation $(2016,202)$, he said that a job satisfaction is a kind of positive emotional reaction and loving the job.

Regarding the job satisfaction, the work environment also determines the teacher's performance. Work environment as stated by (Nitisemito 2007, 66) are all components existed in the environtment of worker which influences their work performance. Robbins as cited in Fathonah and Utami $(2010,3)$ stated that teacher could give their best work performance if the work environtment supports what teachers do and will do. Work environment become important part, it's not only regarding the good condiciton of school infrastructure, but also how the teacher can access the facility and express their idea independently.

Job satisfaction determined from many factors given to them, besides work environment, compensation also plays role in determining and influencing teacher's job satisfaction. Reward, salary, bonus, etc, are the example of compensation. The appropriatness given of compensation towards teachers will contribute positively on their job satisfaction and indirectly impact to education goal of school. Zainal et all $(2016,541)$ stated that compensation is something given to teacher as a reward of their contribution to school. Hasibuan $(2016,118)$ stated that compensation could be income such as money, gift, or other given to employee as a salary of the employee's performances. The compensation given impacts significantly toward teacher's job satisfaction. If the school institution is not able to give the compensation appropriatly, it will also impact negatively towards teacher's job satisfaction, and indirectly will determine school achievement.

The research conducted by Anas $(2013,10)$, Fathonah and Utami $(2010,15)$ which analyzed the compensation and work environment as varibles determined teacher job satisfaction stated that compensation gave positive impact towards teacher's job satisfaction. It is different from Dhermawan, Sudibya, and Utaa $(2012,181)$ and Riansari, Sudiro, and Rofiaty $(2011,819)$ they stated as the result of research that compensation has a positive impact towards teacher job satisfaction, but it is not for work environment. It showed that the best work environment based on this research does not impact directly.

Studies on corelation between compensation and job's satisfaction had conducted by several researchers, Anas $(2013,10-11)$ and $\operatorname{Rizal}(2012,16)$ analyzed the influence between work environment 
and compensation. The results of the studies show that there was some positive significance between compensation, work environment towards the job's satisfaction.

Dhermawan, Sudibyo, and Utama (2012, 181), Rizal (2015, 16) and Riansari, Sudiro, and Rofianti $(2012,819)$, they analyzed the influence of compensation towards job's satisfaction, they concludes there were also positive significance on job's satisfaction as result of good rewards for employees jobs.

\section{Islamic Values on Work Motivation}

In Islamic views there some reference about work motivation, in Qur'an Surah At-taubah verses 105. "say, go for an effort, so Allah and his messenger also beliefers (mu'min) will se your effort, and you'll be returned to Him who knows everything unseen and real, and He informs you what you have done."

In another verse of Qur'an,

Surely Allah does not change the state of a people so as to change the state of themselves (Ar Ra'du:13).

These verses teach the people of Muslim that doing work for their family will be granted some rewards from God. And God gives people a ethic of works that He will never intervene towards what people have done. It means, ethic of progressivism be the major value of Islam.

Another reference tells about rewards towards people who doing hard work for their family. Narated by Imam Ahmad, Rasululullah Muhammad said that Allah loves His people who create and ingenious. Whoever is struggling to earn a living for his family then he is similar to the Mujahid in the way of Allah SWT.

This hadith also tells to people about the degree of work hard for family living. Allah places these efforts similar with Jihad, a hard effort in the way of Allah. Many Muslims believe that Jihad become the first degree of hard working.

In this research, primary observation conducted towards teachers of SMP Negeri in Sub Rayon 02, Pecangaan, Kabupaten Jepara. In this observation, researcher found data identified the low of teacher's job satisfaction. This condition also found in SMP Negeri Kota Cilegon, Rozalinda, Entang, and Setyamidjaya $(2014,2)$ in their primary observation found that $42,82 \%$ teachers are not satisfied with the policy issued by the school headmaster, teacher's who are delayed their career promotion from IVa to IVb is $25,12 \%$, and low appreciation for their achievement both from school or the regional education authority.

These facts show that the job satisfaction happened in several educational institution, and if happened continuously, it will contribute to job dissatisfaction which is correlated indirectly to the quality of teaching and learning process in school. Based on these facts, and the research gap which discusses the job satisfaction factors, this study intends to determine a different angle studies in depth on the influence of compensation and work environtment towards teachers's job satisfaction, especially studies on the teachers of SMP Negeri 02 Pecangaan, Regency of Jepara, Jawa Tengah.

There were some reasons drawing to choose this topic as the underlying issue. They were described follow. First, the issue of job satisfaction in work environtment is still be the popular current discussion topic in many Human and Research Development fields both in company or education institution. The high amount of education fund in Indonesia which increased into $20 \%$ of annual government tax payer money should be followed by the improvement of educators's quality. So, it will contribute to educational management straightly.

The second reason is the topic has a valuable contribution for education management development in Indonesia especially the implementation of Human and Development management. Knowing and applying the case studies in each education institution will lead the learners and 
stakeholders gaining the good awareness in determining some educational issues and policies.

Referring to the existence of logical influence between variables supported by previous studies can be developed framework of thought the following theoretical

\section{Population and Sample}

The population of this study were teachers of SMP Negeri in sub Rayon 02 pecangaan Jepara regency as many as 412 teachers and samples of 81 teachers

\section{Validity Test.}

To measure the validity of the instrument used product moment correlation formula of pearson as follows:

$$
\mathrm{r}_{\mathrm{xy}}=\frac{N \cdot\left(\sum x y\right)-\left(\sum x\right)\left(\sum y\right)}{\sqrt{\left\{N\left(x^{2}\right)-\left(\sum x\right)^{2}\right\}\left\{N\left(\sum y^{2}\right)-\left(\sum y\right)^{2}\right.}}
$$

Information:

$\mathrm{Rxy}=$ The correlation coefficient of variable $\mathrm{X}$ and variable $\mathrm{Y}$

$\mathrm{X}=$ Independent Variable

$\mathrm{Y}=$ Dependent Variable

$\mathrm{N}=$ Number of Respondent

$\Sigma=$ Sigma (Supardi, 2013:169)

\section{Reliability Test.}

For more details, it can be seen in the following formula

$$
r_{11}=\left\lfloor\frac{K}{(k-1)}\right\rfloor\left\lfloor-\frac{\sum \sigma^{2} b}{\sigma^{2} t}\right\rfloor
$$

Information:

$r_{11} \quad=$ Instrument reliability

$\mathrm{k}=$ Number of questions

$\sum \sigma^{2} b=$ Number of question variety

$\sigma^{2} b \quad=$ Total varians

(Supardi 2013, 169)

\section{Hypothesis test.}

Simple reliability test in this research is used to test hypothesis 1 and hypothesis 2 with model of simple linear regression equation as follows:

a : Constanta

$$
\ddot{\mathrm{Y}}=\mathrm{a}+\mathrm{bX}
$$

b : Regression Coeficien for X (Sudjana, 1996 :315)

Double regression test in this research is used to test hypothesis with the model of multiple linear regression equation as follows:

$$
\mathrm{Y}=\mathrm{a}+\mathrm{b}_{1} \mathrm{X}_{1}+\mathrm{b}_{2} \mathrm{X}_{2}
$$




$$
\begin{array}{ll}
\mathrm{Y} & =\text { Job's satisfaction } \\
\mathrm{a} & =\text { constanta } \\
\mathrm{X}_{1} & =\text { Compensation } \\
\mathrm{X}_{2} & =\text { Work Environment } \\
\mathrm{b}_{1} & =\text { regression coeficient } \mathrm{X}_{1} \\
\mathrm{~b}_{2} & =\text { regression coeficient } \mathrm{X}_{2}
\end{array}
$$

Double correlation coefficient is used to know the strength of the influence of independent variables simultaneously with the dependent variable

$$
R_{y .12}=\sqrt{\frac{r_{y 1}^{2}+r_{y 2}^{2}-2 \times r_{y 1} \times r_{y 2} \times r_{12}}{1-r_{12}^{2}}}
$$

$r_{y 1}=$ Correlation Coeficient between $Y_{\text {dan }} X_{1}$

$r_{y 2}=$ Correlation Coeficient between ${ }^{Y}$ dan $X_{2}$

$r_{12}=$ Correlation Coeficient between $X_{1}$ dan $X_{2}$

(Sudjana 1996, 385)

\section{Analysis Requierment test}

\section{Normality Test}

Normality test result in this research used one sample kolmogorov smirnov test, following the rules, if probability significant value $>0,05$ so, data is distributed normal, and otherwise.

Table 4.10. Result of Normality One Sample Kolmogorov Smirnov Test

One-Sample Kolmogorov-Smirnov Test

\begin{tabular}{|ll|r|r|r|}
\hline & & Lompensasi & Lingkungan Keria & \multicolumn{1}{c|}{ Kepuasan Keria } \\
\hline $\mathbf{N}$ & & 81 & 81 & 81 \\
Normal Parameters ${ }^{\mathrm{a}}$ & Mean & 116.3457 & 115.2346 & 123.5309 \\
& Std. Deviation & 15.26283 & 13.54462 & 10.70290 \\
Most Extreme Differences & Absolute & .113 & .143 & .121 \\
& Positive & .077 & .128 & .121 \\
& Negative & -.113 & -.143 & -.061 \\
Kolmogorov-Smirnov Z & & 1.018 & 1.284 & 1.087 \\
Asymp. Sig. (2-tailed) & .251 & .074 & .188 \\
\hline a. Test distribution is Normal. & & & \\
\hline
\end{tabular}

Result of research: probability significance value (Asymp. Sig.) For variable of compensation 0,251, work environment variable 0,074 and job satisfaction variable 0,188 , all more than 0,05 . All three variables are normally distributed.

\section{Liniearity test}

Test criteria, if the value of $r$ (probability value / critical value) $\leq 0.05$ then the distribution patterned linier. 
Table 4.11. The Result of Linierity Test of Compensation towards Job's satisfaction

\begin{tabular}{|c|c|c|c|c|c|c|c|}
\hline & & & $\begin{array}{l}\text { Sum of } \\
\text { Squares }\end{array}$ & df & $\begin{array}{l}\text { Mean } \\
\text { Square }\end{array}$ & $\mathrm{F}$ & Sig. \\
\hline Kepuasan_Kerja * & Between & (Combined) & 7869.390 & 36 & 218.594 & 7.428 & .000 \\
\hline Kompensasi & Groups & Linearity & 6371.835 & 1 & 6371.835 & 216.531 & .000 \\
\hline & 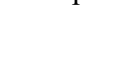 & $\begin{array}{l}\text { Deviation from } \\
\text { Linearity }\end{array}$ & 1497.554 & 35 & 42.787 & 1.454 & .119 \\
\hline & Within Gr & & 1294.783 & 44 & 29.427 & & \\
\hline & Total & & 9164.173 & 80 & & & \\
\hline
\end{tabular}

Result: value $\mathrm{r}$ (probability value / critical value) $0.000 \leq 0,05$ (significant level), it can be concluded the compensation relationship (X1) and job satisfaction (Y) is linear

Tabel 4.12. Result of linearity test Work Environtment towards Job Satisfaction

\begin{tabular}{|lll|r|r|r|r|r|}
\hline \multicolumn{7}{|c|}{ ANOVA Table } \\
\hline
\end{tabular}

Result: value $\mathrm{r}$ (probability value/critical value) $0,000 \leq 0,05$ (significant), it can be concluded that the relation between work environment $\left(\mathrm{X}_{2}\right)$ and job satisfaction $(\mathrm{Y})$ is linear.

\section{Multicolinearity Test}

Table 4.13 Result of Multicolinearity Test

Correlations

\begin{tabular}{|ll|r|r|}
\hline & & Kompensasi & Lingkungan Keria \\
\hline Kompensasi & Pearson Correlation & 1 & $.594^{* * *}$ \\
& Sig. (2-tailed) & 81 & .000 \\
& $\mathrm{~N}$ & $.594^{* *}$ & 81 \\
\hline Lingkungan_Kerja & Pearson Correlation & .000 & 1 \\
& Sig. (2-tailed) & 81 & 81 \\
& $\mathrm{~N}$ & & \\
\hline
\end{tabular}

**. Correlation is significant at the 0.01 level (2-tailed).

The correlation between variable of compensation (X1) and work environment variable (X2) equal to 0,594 still below 0,6 , hence can be said that it's not happened multicoliniearity between independent variable.

\section{Homogenity test}

Homogeneity test used Levene test by using SPSS 16. If the value of sig. $>0$, then the compensation data, work environment, and homogeneous job satisfaction, but if the value of sig $<0$, then the data compensation, work environment, and job satisfaction is not homogeneous. 
Table 4.14. Homogenity Test

\begin{tabular}{|c|c|c|c|}
\hline \multicolumn{4}{|c|}{$\begin{array}{l}\text { Test of Homogeneity of Variances } \\
\text { Value }\end{array}$} \\
\hline Levene Statistic & df1 & $\mathrm{df} 2$ & Sig. \\
\hline 1.119 & 2 & 240 & .328 \\
\hline
\end{tabular}

Result: value sig. $=0.328>0$, it shows that compensation, work environment, and job's satisfaction data are not homogeneus.

\section{Influence of Compensation towards Job Satisfaction}

Hypothesis: there is a positif impact from compensation towards job's satisfaction. Steps are followed.

1. Determining a simple regression equation mode.

Results of analysis as follows:

Table 4.15. Coefisien Of Compensation Regression $\left(\mathrm{X}_{1}\right)$ towards job's satisfaction $(\mathrm{Y})$.

\begin{tabular}{|c|c|c|c|c|c|}
\hline & & gerte & & & \\
\hline \multirow[t]{2}{*}{ Model } & Unstandardized & ficients & $\begin{array}{l}\text { Standardized } \\
\text { Coefficients }\end{array}$ & \multirow[b]{2}{*}{$\mathrm{T}$} & \multirow[b]{2}{*}{ Sig. } \\
\hline & Std. Error & Beta & & & \\
\hline (Constant) & 55.501 & 5.110 & & 10.862 & .000 \\
\hline Kompensasi & .585 & .044 & 834 & 13.426 & .000 \\
\hline
\end{tabular}

a. Dependent Variable: Kepuasan_Kerja

Result: model of compensation relationship to job satisfaction expressed by equation $\mathrm{Y}=$ $55,501+0,585 \mathrm{X}_{1}$

2. Determining Significance Models

Results as follows:

Tabel4.16. Significance of compensation relationship model (X1) to job satisfaction (Y)

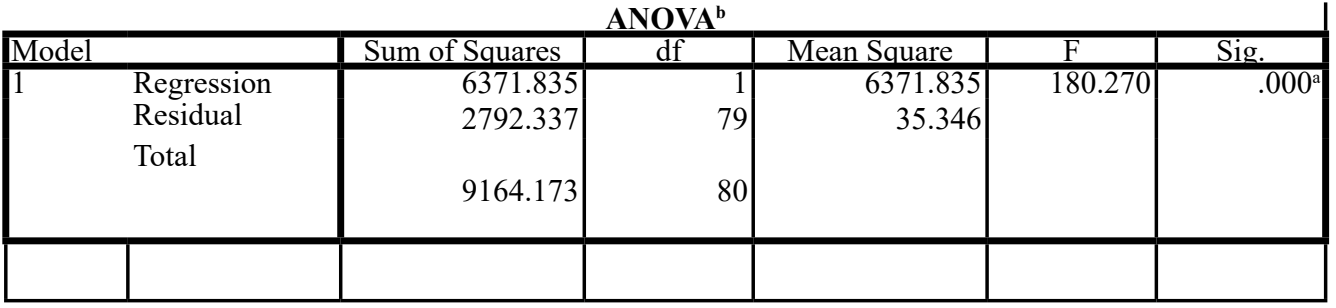

Results: F value equal to 180,270 with significance $0,000 \leq 0,05$ so significant regression model which means model of compensation relationship with job satisfaction with regression equation $\mathrm{Y}=55,501+0,585 \mathrm{X} 1$ is significant or accepted.

3. Determining the relation strenght

The coefficient of product moment correlation is 0.834 as follows:

Table 4.17. Relation between compensation $\left(\mathrm{X}_{1}\right)$ towards job's satisfaction

\begin{tabular}{|ll|r|r|}
\hline \multicolumn{2}{|c|}{ Correlations } \\
\hline \multicolumn{2}{|c|}{ Compensation } & Compensation & Job satisfaction \\
& Pearson Correlation & 1 & $.834^{* * *}$ \\
& Sig. (2-tailed) & 81 & .000 \\
& $\mathrm{~N}$ & $.834^{* *}$ & 81 \\
\hline Job satisfaction & Pearson Correlation & .000 & 1 \\
& Sig. (2-tailed) & 81 & 81 \\
& $\mathrm{~N}$ &
\end{tabular}

Result of research: correlation coefficient between compensation with job satisfaction is 0,834 . 
Because the sig value. (2-tailed) $\leq 0.05$ ), then there is a significant relationship between the variable compensation and job satisfaction. That is, the higher the compensation determines the higher the teacher's job satisfaction.

4. Determining for coefficient of determination

Table 4.18. Contribution of compensation (X1) to job satisfaction (Y)

\begin{tabular}{|c|c|c|}
\hline \multicolumn{3}{|c|}{ Model Summary } \\
\hline Model & R Square & \begin{tabular}{|l|l|l|} 
Adiusted R Square & Std. Error of the Estimate \\
\end{tabular} \\
\hline 1 & $.834^{\mathrm{a}}$ & 5.94525 \\
\hline
\end{tabular}

Results: contribution of variable of compensation to job satisfaction variable is equal to 0,695 or equal to $69,5 \%$.

The result of simple regression analysis shows that the model of Compensation relationship to Job satisfaction is expressed by the equation $\mathrm{Y}=55,501+0,585 \mathrm{X} 1$. Based on the table Anova note that the value of $F$ equal to 180.270 with a significance of $0.000 \leq 0.05$ so a significant regression model which means the model of compensation relationship with job satisfaction with regression equation $\mathrm{Y}=55,501+0.585 \mathrm{X} 1$ significant or acceptable truth. Thus it can be interpreted that every increase of one unit of compensation will raise job satisfaction of 0,585 at constant 55,501

The relationship between compensation and job satisfaction is expressed by product moment correlation coefficient of 0.834 . Because the sig value. (2-tailed) $\leq 0.05$ ), then there is a significant relationship between the variable compensation and job satisfaction. This means that the higher the compensation of teachers the higher the satisfaction of their work. The amount of contribution between variable compensation to job satisfaction variable is equal to 0,695 or $69,5 \%$.

\section{The Influence of Work Environment towards Job's Satisfaction}

Hypothesis: there were positive influence from work environment towards job satisfaction. Steps as follows:

1. Determining model of regression equation line.

Result of simple regression analysis to test hypothesis as follows:

Table 4.19. Coefisient of regression work environment towards job's satisfaction

\begin{tabular}{|c|c|c|c|c|c|}
\hline \multirow{2}{*}{\begin{tabular}{|l} 
Model \\
\\
\\
B
\end{tabular}} & \multicolumn{2}{|c|}{ Unstanrdardized Coefficients } & \multirow[t]{2}{*}{$\begin{array}{l}\text { Standardized } \\
\text { Coefficients }\end{array}$} & \multirow[b]{2}{*}{1} & \multirow[b]{2}{*}{ Sig. } \\
\hline & Std. Error & Beta & & & \\
\hline (Constant) & 56.157 & 6.939 & & 8.093 & .000 \\
\hline Work Environment & .585 & .060 & .740 & 9.776 & .000 \\
\hline
\end{tabular}

Result: that model of work environment relation to job satisfaction is expressed by equation $\mathrm{Y}$ $=56,157+0,585 \mathrm{X}_{2}$

2. Determining the model of significance

Tabel 4.20. Significance model of relation between work environment $\left(\mathrm{X}_{2}\right)$ towards job satisfaction (Y). 


\begin{tabular}{|c|c|c|c|c|c|}
\hline Model & Sum of Squares & df & Mean Square & $\bar{F}$ & Sig. \\
\hline Regression & 5016.991 & 1 & 5016.991 & 95.569 & $.000^{2}$ \\
\hline Residual & 4147.182 & 79 & 52.496 & & \\
\hline Total & o9164.173 & 80 & & & \\
\hline
\end{tabular}

a. Predictors: (Constant), Work Environment

b. . Dependent Variable: Job Satisfaction

Result of research: $F$ value equal to 95,569 with significance $0,000 \leq 0,05$ means work environment relation model with job satisfaction with regression equation $\mathrm{Y}=56,157+0,585$ $\mathrm{X}_{2}$ is significant or accepted.

3. Determining the relation strenght

Table 4.21. The relation strength between work environment and job satisfaction.

\begin{tabular}{|ll|r|r|}
\hline \multicolumn{2}{|c|}{ Correlations } \\
\hline Job satisfaction & Kepuasan_Kerja & Lingkungan_Kerja \\
& Pearson Correlation & 1 & $.740^{* *}$ \\
& Sig. (2-tailed) & 81 & .000 \\
$N$ & $.740^{* *}$ & 81 \\
\hline Work Satisfaction & Pearson Correlation & .000 & 1 \\
& Sig. (2-tailed) & 81 & 81 \\
& $N$ &
\end{tabular}

Result: the correlation coefficient between work environment and job satisfaction is 0,740 . Because the value of sig. (2-tailed) $=0.00 \leq 0.05$, then there is a significant relationship between work environment variables and job satisfaction.

4. Determining Coefficient Determination

The amount of work environment contribution to job satisfaction as follows

Table 4.22. Contribution of work environment $\left(\mathrm{X}_{2}\right)$ towards Job Satisfaction (Y).

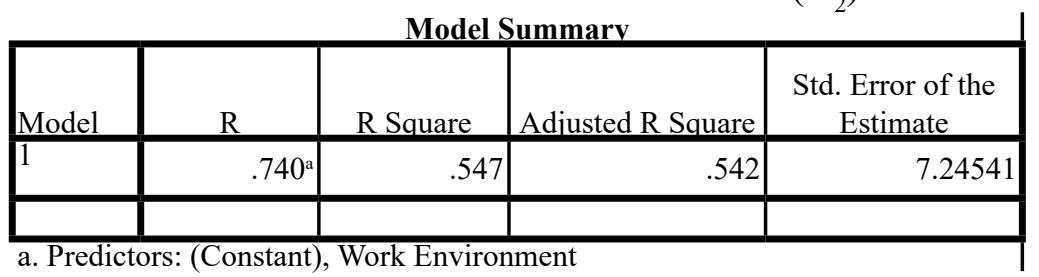

contribution of work environment variable to job satisfaction variable is equal to 0,74 or equal to $54,7 \%$.

The result of simple regression analysis shows that the relationship model of Work environment to Job satisfaction is expressed by $\mathrm{Y}=56,157+0,585 \mathrm{X} 2$. Based on the table anova note that the value of $F$ of 95.569 with a significance of $0.000 \leq 0.05$ so a significant regression model which means the relationship model Work environment with job satisfaction with regression equation $\mathrm{Y}=56.157+0.585 \mathrm{X} 2$ significant or acceptable truth. Thus it can be interpreted that every increase of one unit of Compensation will raise job satisfaction of 0.585 at constant 56.157.

The strength of the relationship between work environment with job satisfaction is expressed by product moment correlation coefficient of 0.740 . Because the sig value. (2-tailed) $=0.00 \leq 0.05$, then there is a significant relationship between work environment variable with job satisfaction. This means that the higher work environment, the higher the job satisfaction. The amount of contribution between work environment variable to the variable Job satisfaction is equal to 0.547 or equal to $54.7 \%$. 


\section{The Influence of Compensation and Work Environtment towards Job Satisfaction}

Hypothesis: there is a positive influence of compensation and work environment together towards Job Satisfaction

1) Determining Double Regression Equation Model

Table 4.23. Coeficient of Compensation regression $\left(\mathrm{X}_{1}\right)$ and work environment $\left(\mathrm{X}_{2}\right)$ towards job satisfaction $(\mathrm{Y})$

\begin{tabular}{|c|c|c|c|c|c|}
\hline \multicolumn{6}{|c|}{ Coefficients $^{\mathrm{a}}$} \\
\hline \multirow[t]{2}{*}{ Model } & \multicolumn{2}{|c|}{$\begin{array}{l}\text { Unstandardized } \\
\text { Coefficients }\end{array}$} & $\begin{array}{l}\text { Standardized } \\
\text { Coefficients }\end{array}$ & \multirow[b]{2}{*}{$\mathrm{T}$} & \multirow[b]{2}{*}{ Sig. } \\
\hline & Std. Error & Beta & & & \\
\hline (Constant) & 39.414 & 5.105 & & 7.721 & .000 \\
\hline Work environment & .299 & .051 & .378 & 5.824 & .000 \\
\hline Compensation & .427 & .045 & .609 & 9.393 & .000 \\
\hline
\end{tabular}

a. Dependent Variable: job satisfaction

Results: model of compensation relationship and work environment to job satisfaction expressed by equation $\mathrm{Y}=39,414+0,427 \mathrm{X}_{1}+0,299 \mathrm{X}_{2}$

2) Determining Significance Model

Test result of regression as follows:

Table 4.24. Model of compensation significance relation $\left(\mathrm{X}_{1}\right)$ and work environment $\left(\mathrm{X}_{2}\right)$ towards job satisfaction (Y).

\begin{tabular}{|ll|r|r|r|r|r|}
\hline Model & & Sum of Squares & df & Mean Square & F & Sig. \\
\hline 1 & Regression & 7218.107 & 2 & 3609.054 & 144.654 & $.000^{\text {a }}$ \\
Residual & 1946.065 & 78 & 24.950 & & \\
& Total & 9164.173 & 80 & & & \\
\hline
\end{tabular}

a. Predictors: (Constant), compensation, Work Environment

b. Dependent Variable: Job satisfaction

Results: value of $\mathrm{F}$ equal to 144,654 with significance $0,000 \leq 0,05$ become significant regression model which mean model of compensation relationship and work environment with job satisfaction with regression equation $Y=39,414+0,427 \mathrm{X}_{1}+0,299 \mathrm{X}_{2,}$ is accepted.

3) Determiningon the relation strenght

Tabel 4.25. Double Correlation coefficient (R)

Model Summary ${ }^{b}$

\begin{tabular}{|l|r|r|r|c|}
\hline Model & $\mathrm{R}$ & $\mathrm{R}$ Square & $\begin{array}{c}\text { Adjusted R } \\
\text { Square }\end{array}$ & $\begin{array}{c}\text { Std. Error of the } \\
\text { Estimate }\end{array}$ \\
\hline 1 & $.887^{\mathrm{a}}$ & .788 & & .782 \\
\end{tabular}

b. Dependent Variable: job satisfaction

Results: the value of multiple correlation coefficient is 0.887 . So, the compensation relationship (X1) and work environment (X2) are together to the job satisfaction (Y) of 0.788, which fall into the high category. 
4) Determining Determination Coeficient

Table 4.26. The Contribution of compensation $\left(\mathrm{X}_{1}\right)$ dand work environment $\left(\mathrm{X}_{2}\right)$ towards job satisfaction $(\mathrm{Y})$

\begin{tabular}{|l|r|r|r|r|}
\hline Model & R & R Square & Adjusted R Square & $\begin{array}{c}\text { Std. Error of the } \\
\text { Estimate }\end{array}$ \\
\hline 1 & $.887^{\mathrm{a}}$ & .788 & .782 & 4.99495 \\
\hline
\end{tabular}
a. Predictors: (Constant), compensation, work environment
b. Dependent Variable: job satisfaction

Results: the amount of job satisfaction variables that can be affected compensation and work environment is 0.788 or $78.8 \%$, while $21.2 \%$ influenced by other variables

Results of multiple regression analysis between compensation and work environment to job satisfaction can be seen that the model of Compensation relationship and work environment to job satisfaction is expressed by the equation $\mathrm{Y}=39.414+0.427 \mathrm{X} 1+0.299 \mathrm{X} 2$

Based on the table anova note that the value of $\mathrm{F}$ for 144.654 with a significance of $0.000 \leq$ 0.05 so a significant regression model which means the model of compensation relations and work environment with job satisfaction with regression equation $\mathrm{Y}=39.414+0.427 \mathrm{X} 1+0.299 \mathrm{X} 2$. accepted the truth. Thus it can be interpreted that every increase of one unit of compensation and work environment will raise job satisfaction equal to 0,726 at constant 39,414

The strength of the relationship between compensation and work environment on job satisfaction obtained from a double correlation analysis of 0.887 . So the correlation between compensation and work environment together to job satisfaction is significant, meaning that the higher the compensation and work environment, the higher the job satisfaction. The amount of contribution between compensation and work environment to job satisfaction is 0.788 or $78.8 \%$, while $21.2 \%$ influenced by other factors.

\section{Conclusion}

The result of double regression analysis between compensation and work environment to job satisfaction can be seen that model of compensation and work environment to job satisfaction is expressed by equation $\mathrm{Y}=39,414+0,427 \mathrm{X} 1+0,299 \mathrm{X} 2$. The table anova noted that the value of $F$ for 144.654 with a significance of $0.000 \leq 0.05$ so a significant regression model which means the model of compensation relations and work environment with job satisfaction with regression equation $\mathrm{Y}=39.414+0.427 \mathrm{X} 1+0.299 \mathrm{X} 2$ accepted truth. So it can be understood that every increase of one unit of compensation and work environment will raise job satisfaction equal to 0,726 at constant 39,414. Thus the proposed hepotisis is acceptable.

Table anova noted that the value of $F$ for 144.654 with a significance of $0.000 \leq 0.05$ so a significant regression model which means the model of compensation relations and work environment with job satisfaction with regression equation $\mathrm{Y}=39.414+0.427 \mathrm{X} 1+0.299 \mathrm{X} 2$ accepted truth. So it can be understood that every increase of one unit of compensation and work environment will raise job satisfaction equal to 0,726 at constant 39,414 . Thus the proposed hypothesis is acceptable

Based on the results of research and discussion above, it can be concluded as follows: (1) There is a positive and significant influence Compensation to job satisfaction of $69.5 \%$, (2) 
There is a positive and significant impact of work environment on Job satisfaction of $54.7 \%$, (3) Compensation gives effect of $69,5 \%$ to job satisfaction and work environment give influence equal to $54,7 \%$ to teacher work satisfaction, (4) While compensation and work environment together contributed $78.8 \%$ to teacher work satisfaction. 


\section{References}

Alek S. Nitisemito. (2007).Manajemen Personalia. Jakarta: Ghaia

Anas, Khaidir. (2013). Pengaruh Kompensasi dan Lingkungan Kerja Terhadap Kepuasan Kerja Karyawan PT. Karya Mitra Muda. Jurnal Manajemenejournal.unp.ac.id

Anoraga, Panji. (2014). Psikologi Kerja, Jakarta: Rineka Cipta.

Arikunto, Suharsimi. (2002). Prosedur Penelitian, Suatu Pendekatan Praktek. Jakarta: PT. Rineka Cipta.

Dessler, Gary. (2011). Manajemen Sumber Daya Manusia, Jakarta : Indeks.

Fathonah, Siti dan Utami Ida. (2010). Pengaruh Kompensasi, Pengembangan Karir, Lingkungan Kerja, dan Komitmen Organisasi terhadap Kepuasan Kerja Pegawai Sekretariat Daerah Kabupaten Karanganyar dengan Keyakinan Diri (Self Efficacy) sebagai Variabel Pemoderasi. E-Journal STIE AUB Surakarta

Fauzi, Ahmad. (2010). Pengaruh Kepemimpinan, Kecerdasan Emosional, dan Motivasi Kerja Terhadap Kepuasan Kerja Guru SMA

Griffin, Rifqi. W. (2004). Manajemen. Edisi ke Tujuh. Jakarta: Erlangga.

Hasibuan, S.P. Malayu. 2016. Manajemen Dasar. Pengertian dan Masalah. Jakarta: Bumi Aksara.

Hendri, Edduar. (2012). Pengaruh Lingkingan Kerja Fisik dan Non Fisik Terhadap Kepuasan Kerja Karyawan pada PT Asuransi Wahana Tata Cabang Palembang.

Husein Umar. (2013). Metode Penelitian untuk Skripsi dan Tesis Bisnis. Cetakan ke-6. Jakarta: PT Raja Grafindo Persada.

Kadarisman, M. (2012). Manajemen Kompensasi. jakarta: Rajawali Pers.

Naibaho, H., \& Adi, F. (2012). Pengaruh Lingkungan Kampus terhadap Motivasi Belajar Mahasiswa (Studi Kasus Universitas Pelita Harapan Surabaya). Jurnal Manajemen Pemasaran.

Permatasari, Andi Ulfa Nur. (2014). Pengaruh Kompensasi dan lingkungan kerja terhadap kepuasan karyawan perusahaan air minum Makasar.

Rebore, Ronald W. (2011). The Essentials OF Human Resources Administration in Education.

Rizal, Fitriana. (2015). Pengaruh Lingkungan Kerja dan Kompensasi Terhadap Kepuasan Kerja Karyawan Pada PT. Statistika Mitra Srana Padang

Robbins, Stephen P. Judge, Timothy. 2015. Perilaku Organisasi. Jakarta : Salemba Empat.

Seyfarth, John T. (2002). Human Resources Managemen for Effective Schools Boston : A Pearson Education Company.

Sedarmayanti. (2016). Sumber Daya Manusia . Bandung: Penerbit PT Revika Aditama.

Sedarmayanti. (2009). Sumber Daya Manusia dan Produktivitas Kerja. Bandung: Mandar Maju. Simamora, Henry. (2004). Manajemen Sumber Daya Manusia edisi 3. Yogyakarta: STIE YKPN Sugiyono. (2015). Metode Penelitian Kuantitatif, Kualitatif dan R \& D. Bandung: Alfabeta. Sudjana. (1996). Metoda Statistika. Bandung: Tarsito.

Sunyoto, Danang. (2015) .Penelitian sumber daya menusia.Yogyakarta: Center of Academic Publising Service.

Supardi. (2013). Aplikasi Statistik dalam penelitian Jakarta ; Adikita.

Triatna. Cepi. (2015). Perilaku Organisasi CV. Citra Praya.

Undang-undang No. 14 Tahun 2005 tentang Guru dan Dosen.

Zainal, Veithzal Rivai., Ramly, Mansyur., Mutis, Thoby dan Arafah, Willy. (2015). Manajemen Sumber Daya Manusia Untuk Perusahaan Dari Teori ke Praktik. Jakarta : raja Grafindo Persada. 